\title{
Continuous Practice of Conservation Agriculture for 3-5 Years in Intensive Rice-Based Cropping Patterns Reduces Soil Weed Seedbank
}

\author{
Mohammad Mobarak Hossain ${ }^{1}\left(\right.$ D, Mahfuza Begum ${ }^{2}$, Abul Hashem ${ }^{3}$, Md. Moshiur Rahman ${ }^{2}$, \\ Md. Enamul Haque ${ }^{4}$ and Richard W. Bell ${ }^{4, *}$ (D)
}

\section{check for} updates

Citation: Hossain, M.M.; Begum, M.; Hashem, A.; Rahman, M.M.; Haque, M.E.; Bell, R.W. Continuous Practice of Conservation Agriculture for 3-5 Years in Intensive Rice-Based Cropping Patterns Reduces Soil Weed Seedbank. Agriculture 2021, 11, 895. https://doi.org/10.3390/ agriculture11090895

Academic Editors: Gunnar Kirchhof and Joshua O. Ogunwole

Received: 15 August 2021

Accepted: 15 September 2021

Published: 17 September 2021

Publisher's Note: MDPI stays neutral with regard to jurisdictional claims in published maps and institutional affiliations.

Copyright: (C) 2021 by the authors Licensee MDPI, Basel, Switzerland. This article is an open access article distributed under the terms and conditions of the Creative Commons Attribution (CC BY) license (https:// creativecommons.org/licenses/by/ $4.0 /)$.
1 Rice Breeding Innovation Platform, International Rice Research Institute, Pili Drive, Los Baños 4031, Laguna, Philippines; mm.hossain@irri.org

2 Department of Agronomy, Bangladesh Agricultural University, Mymensingh 2202, Bangladesh; mahfuza.agron@bau.edu.bd (M.B.); rahmanag63@bau.edu.bd (M.M.R.)

3 Department of Agriculture and Food, Government of Western Australia, 75 York Road, Northam, WA 6401, Australia; hashemau71@gmail.com

4 Centre for Sustainable Farming Systems, Future Food Institute, Murdoch University, South Street, Murdoch, WA 6150, Australia; e.haque@murdoch.edu.au

* Correspondence: r.bell@murdoch.edu.au

\begin{abstract}
When farmers first shift from conventional tillage (CT) to conservation agriculture (CA) practices, the control of weeds may be more difficult, due to the absence of tillage. However, continuous CA, over several years, may alter the weed seedbank. The nature of the weed seedbank changes over time, in intensively cropped rice-based rotations that are typical of the Eastern Gangetic Plain, are not well understood. Two on-farm CA experiments were sampled (in Beluapara after 3 years and Digram after 5 years) in Bangladesh for the effects of strip planting (SP) and bed planting (BP) at both the sites, plus no-tillage (NT) in Beluapara, and increased retention of the residue of previous crops ( $20 \%$ vs. $50 \%$ ). The conventional tillage (CT) and $20 \%$ residue was the control treatment. The weed seedbank in $0-15 \mathrm{~cm}$ soil was quantified by assessing the emergence of weeds from soils collected from the field after irrigation, (Boro) rice in Digram and wheat in Beluapara, and they were allowed to emerge in trays in a shade-house experiment. The year-round count of emerged weeds at both the locations revealed the fewest number of weed species (especially broadleaf weeds), and the lowest weed density and biomass in SP, followed by CT, BP, and NT, with $50 \%$ crop residue mulch. Relative to $\mathrm{CT}$, the $\mathrm{SP}, \mathrm{BP}$, and NT produced relatively more perennials weeds, as follows: Alternanthera denticulata ((R.) Brown.), Cyperus rotundus (L.), Dentella repens (L.), Jussia deccurence (Walt.), Leersia hexandra (L.), and Solanum torvum (Sw.), which was the opposite of CT that was enriched with the following annual weeds: Cyperus iria (L.), Digitaria sanguinalis (L.), Euphorbia parviflora (L.), Fimbristylis miliacea (L.), Lindernia antipoda (L.), L. hyssopifolia (L.), and Monochoria hastata (L.). The soil weed seed bank reduced by 13\% in SP, while it increased by $19 \%$ and $76 \%$ in BP and NT, respectively, compared with CT. The species diversity reduced in SP and NT, by $24 \%$ and $11 \%$, respectively, but increased by $2 \%$ in BP. In $50 \%$ residue, the soil weed seed bank and species diversity reduced by $16 \%$ and $14 \%$, respectively, relative to that of $20 \%$ residue. The continuous practice of CA, for 3 or more years, in two rice-based crop rotations, decreased the size of the weed seedbank, but increased the relative proliferation of specific perennial weeds.
\end{abstract}

Keywords: annual weeds; crop residue; perennial weeds; reduced tillage; strip planting

\section{Introduction}

Conservation agriculture (CA) has a major influence on the relative abundance of weed species, while weed control is perceived as one of the most challenging issues with the initial adoption of CA [1]. Due to a cessation of tillage, the composition and dynamics of weeds in the soil weed seedbank will change, compared to conventional tillage that leads to 
shifts in the weed communities [2]. Minimum soil disturbance of the CA system generally favors the emergence of perennial weed species, relative to annual weed species in the seedbank [3]. It is reported to encourage perennial weeds, such as Cyperus rotundus L., Saccharum spontaneum L., and Sorghum halepense (L.) Pers, in the soil weed seedbank of minimally disturbed soil, since tubers and rhizomes present underground in soil are not buried or uprooted [4]. Also, in no-tillage systems, the annual grass populations usually increase [5], concurrent with a decrease in the populations of dicotyledonous weeds. On the other hand, the seedbank of annual and perennial grasses, perennial dicot species, wind-disseminated species, and volunteer crop species was reported to increase, and the annual dicot species was reported to decrease in a reduced tillage (RT) system [6]. For example, the seedling density of Amaranthus spp. was much higher in the no-till soils than the tilled soils [7]. Notwithstanding the above effects of decreased soil disturbance by CA on the weed seedbank, there have been no comparable studies in the intensive, triple-cropping systems, where there is an annual period of soil submergence for wetland rice crops.

Despite its widespread global adoption, in Bangladesh, experimentation on CA began in around 2005 [8], to adapt its practices for smallholder farms. However, studies on weed species composition in the soil seedbank, and their changes after several years of CA practice, have rarely been examined. Tillage practices, crop rotation, and weed control practices may change the weed seed density in the soil, which affects the soil weed seedbank and the efficacy of weed control practices. Changes in the weed seedbank, due to crop production practices, are an important predictor of subsequent weed problems. Information on the effect of strip tillage and crop residue retention in the intensive cropping pattern on the soil weed seedbank might be a useful background for sustainable weed management in CA. Hence, in this first-ever study of the soil weed seedbank in long-term CA experiments, at two locations in Bangladesh, we assessed the weed response to tillage practice and residue retention under CA in rice-based cropping systems. The aim was to determine how weed seedbanks changed over time, and to predict changes in weed management practices that are needed to prepare for more widespread adoption of CA on smallholder, rice-based cropping systems.

\section{Materials and Method}

\subsection{Experimental Site, Edaphic and Climatic Environments}

A shade-house experiment was conducted during 2 January-29 December 2016, at the Department of Agronomy, Bangladesh Agricultural University, $24.75^{\circ} \mathrm{N}$ and $90.50^{\circ} \mathrm{E}$. The research site was characterized by heavy monsoon rainfall with occasional gusty wind during April-September and low precipitation with moderately low temperature during October-March. The average maximum temperature varied from $32.3-33.5^{\circ} \mathrm{C}$ during April-June while January was the coldest month. About 95\% rainfall was received during April-September.

\subsection{Cropping History at the Sites of On-Farm CA Experiments \\ 2.2.1. Treatments}

The two CA experiments were conducted in Beluapara and Digram, Bangladesh. In Digram $\left(24^{\circ} 22^{\prime} \mathrm{N}\right.$ and $\left.88^{\circ} 36^{\prime} \mathrm{E}\right)$, cropping sequences were monsoon (T. aman) rice-mustardirrigated (Boro) rice, T. aman rice-mungbean-lentil, and T. aman rice-lentil-jute during 2010-2015. The crops were grown under conventional tillage (CT), strip planting (SP) and bed planting (BP) practices. In Beluapara $\left(23^{\circ} 39^{\prime} 45^{\prime \prime} \mathrm{N}\right.$ and $\left.89^{\circ} 29^{\prime} 39^{\prime \prime} \mathrm{E}\right)$, the T. aman rice-wheat-jute cropping pattern was followed during 2012-2015. Here, in addition to the three tillage practices (CT, SP, BP), no-tillage (NT) was included. Two levels of crop residue (height basis) were retained across the experimental sites. At all locations $20 \%$ residue $\left(\mathrm{M}_{20}\right)$ was comparable to the standard residue level retained on farmers' fields $\left(1-1.6 \mathrm{t} \mathrm{ha}^{-1}\right)$, while $50 \%$ residue $\left(\mathrm{M}_{50}\right)$ represented the increased residue retention (3-4 tha $\left.{ }^{-1}\right)$. In $\mathrm{M}_{50}$, 
previous crops were harvested keeping $50 \%$ by height of the standing straw/stubbles of cereal/non-cereal crops on the respective plots.

\subsubsection{Tillage Operations}

The CT was conducted by a two-wheel tractor (2WT) comprising four rotary tillage passes and cross plowing followed by sun-drying for two days (in non-rice crops), finally by inundation and levelling (in rice). The SP was conducted by a versatile multi-crop planter (VMP) in a single-pass operation [9]. Strips were prepared for four rows. In each line, about $6 \mathrm{~cm}$ wide and $5 \mathrm{~cm}$ deep tilled strips were made (that preserved about $80 \%$ untilled soil) in the untilled flat land by the rotary blades operated by the VMP, and seed and fertilizers were placed by a tine/furrow opener of the VMP in a single pass. In case of NT, the land was not tilled, but seed and fertilizer were dropped in furrows made by a furrow opener. In BP, raised beds $(15 \mathrm{~cm}$ high and $60 \mathrm{~cm}$ wide on the top with $30 \mathrm{~cm}$ wide furrows) were made with the bed planting configuration of the VMP.

\subsubsection{Weeding Regimes}

In CT, weeds emerging during crop growth were controlled by hand weeding in all crops. Hand weeding (HW) was conducted at 25,45 , and 65 days after transplanting or sowing (DAT/S) in rice and wheat, while HW was conducted at 25 and 45 DAS in mustard, jute, mungbean, lentil and chickpea. On the other hand, in SP, BP, and NT, weeds were controlled using appropriate herbicides for each crop. Here, glyphosate (41\%) @ 3.7 L was applied at 3 days before tillage/planting. Pendimethalin (33 EC) @ $2.5 \mathrm{~L}$ was applied at 3 DAT / $S$ in rice and wheat, but immediately after seeding of mustard, jute, lentil, mungbean and chickpea. Isoproturon (75 WP) was applied in mustard at 15 DAS @ $0.75 \mathrm{~L}$. Ethoxysulfuron ethyl and carfentrazone-ethyl $(50 \%)+$ isoproturon $(0.75 \%)$ was applied at 25 DAT/S @ $100 \mathrm{~g}$ and $1.5 \mathrm{~kg}$ in rice and wheat, respectively. Fenoxaprop-p-ethyl at 25 DAS @ 0.75 L was applied in jute, mungbean, lentil, chickpea. The doses of all herbicides were according to their product label on a per ha basis.

\subsection{Soil Sampling Procedure and Experimental Set-Up}

The soil was collected from the field of all locations from 0 to $15 \mathrm{~cm}$ soil depth. Five samples from each plot; hence 280 samples, were collected using a stainless steel pipe of $5 \mathrm{~cm}$ diameter following the " $W$ " shape sampling pattern in each plot as described by Chancellor [10]. After collection, samples were tagged and appropriately bagged for transportation to the shade-house. After that, sub-samples from each plot were combined, and approximately one kilogram of soil was placed immediately in an individual circular plastic tray of $33 \mathrm{~cm}$ diameter filled to $3 \mathrm{~cm}$ depth. Trays were set in the shade-house following a completely randomized design, replicated four times. Each tray represented a plot and there was a total of 224 trays in the shade-house.

\subsection{Weed Seed Emergence and Data Collection in Shade-House}

Emerged seedlings were identified, counted, and removed at 30-day intervals using the seedling keys of Chancellor [10]. Unnamed seedlings were transferred to another pot and grown to maturity to facilitate identification. After the removal of each batch of seedlings, soils were air-dried, thoroughly mixed, and re-wetted to permit further emergence. The number of seedlings emerged was converted to the number $\mathrm{m}^{-2}$ using the following formula: area $=\pi \mathrm{r}^{2}$, where $\pi=3.1416, \mathrm{r}=$ radius of the tray $=16.5 \mathrm{~cm}$.

The weed biomass was assessed by recording the dry matter for each species in $\mathrm{g} \mathrm{m}^{-2}$ after oven drying the weed samples at $70^{\circ} \mathrm{C}$ for $72 \mathrm{~h}$.

\subsection{Similarity Index}

We used both the qualitative and the quantitative similarity index of SØrensen [11] to compare the resemblance of weed communities of seedbank in the different treatments used in the field as follows: 
The qualitative index $(\%)=[2 \mathrm{C} /(\mathrm{A}+\mathrm{B})] \times 100$

( $C$ denotes the number of common species in the two populations, $\mathrm{A}+\mathrm{B}$ denotes total number of species in each of two populations)

The quantitative index $(\%)=[2 \mathrm{Nc} /(\mathrm{Na}+\mathrm{Nb})] \times 100$

(Nc denotes sum of the smallest numbers of common species in two populations, $\mathrm{Na}+\mathrm{Nb}$ denote the number of all weeds in each of two populations)

\subsection{Diversity Indices}

The degree of diversity of weed composition in the seedbank was analyzed using the following:
(A) Shannon's diversity index, $\mathrm{H}^{\prime}=-\sum(\mathrm{Pi}) \times \ln (\mathrm{Pi})[12]$
(B) Simpson's dominance index, $\mathrm{SI}=\sum(\mathrm{Pi})^{2}$ [13]
( $\mathrm{Pi}$ is the probability of species occurrence in the sample)

\subsection{Data Analysis Methods}

We used STAR software to analyze all data following the standard procedure of two-way analysis of variance and Duncans' multiple range test at $p \leq 0.05$.

\section{Results}

\subsection{Weed Seedbank Composition under Different Tillage and Residue Mulch}

In Beluapara, the CT $+20 \%$ residue produced 14 weed species $\left(3,708\right.$ plants $\left.\mathrm{m}^{-2}\right)$, but at $50 \%$ residue, 12 weed species $\left(2,956\right.$ plants $\mathrm{m}^{-2}$ ) emerged (Table 1$)$. The SP $+20 \%$ residue produced 10 weed species $\left(2,966\right.$ plants $\left.\mathrm{m}^{-2}\right)$, while the $\mathrm{SP}+50 \%$ residue mulch produced nine species $\left(2,365\right.$ plants $\left.\mathrm{m}^{-2}\right)$, but one perennial species, Leersia hexandra L., was absent. In BP with $20 \%$ residue $\left(4,153\right.$ plants $\left.\mathrm{m}^{-2}\right), 17$ species were found, but with $50 \%$ residue, 15 weed species $\left(3,427\right.$ plants $\left.\mathrm{m}^{-2}\right)$ were found. In the case of NT with $20 \%$ residue, there were 19 weed species $\left(6,881\right.$ plants $\left.\mathrm{m}^{-2}\right)$, but in NT with $50 \%$ residue, only 16 weed species $\left(6,064\right.$ plants $\left.\mathrm{m}^{-2}\right)$ emerged.

The least diversified weed seedbank composition (based on the lowest diversity index and highest dominance index) was found in the $\mathrm{SP}+50 \%$ residue (2.28 and 0.63$)$, followed by CT (2.39 and 0.51$), \mathrm{BP}(2.76$ and 0.51$)$, and NT (2.93 and 0.49$)$, all with $50 \%$ residue, while the NT $+20 \%$ residue was the most diversified ( 2.95 and 0.53 ). The CT $+20 \%$ residue (2.61 and 0.53 ) was more diversified than the SP $+50 \%$ residue (Table 1). The highest number of weed seed species producing the highest number of plants was in NT. The higher and lower values of diversity and dominance indices, respectively indicates the most diversified and the species-enriched weed seedbank composition. In NT, we found the dominance of the following perennial species: Alternanthera denticulata, Dentella repens, Solanum torvum, Cyperus rotundus, and Eleusine indica over the annual species (Table 1).

Compared to NT with 20 or $50 \%$ residue, the weed seedbank of BP was less diversified, with diversity indices of 2.78 and 2.76, respectively. The BP also favored the occurrence of the following perennial weeds over annuals: Dentella repens, Jussia deccurence, Cyanotis axillaris, Cyperus rotundus, Eleusine indica, Digitaria sanguinalis, Commelina benghalensis, Echinochloa colonum, and Lindenia antipoda (Table 1).

The weed pool in SP was described by the lowest and highest values of diversity and domination indices, respectively, suggesting the least diversified species composition, with the dominance of the following specific perennial species: Alternanthera denticulata, Leersia hexandra, Dentella repens, Jussia deccurence, Solanum torvum, Hedyotis orymbose, and Echinochloa colonum over the annual species in SP (Table 1). 
Table 1. Seedbank composition and weed density (plants $\mathrm{m}^{-2}$ ) as affected by tillage and residue mulch treatments in Beluapara after 3 years.

\begin{tabular}{|c|c|c|c|c|c|c|c|c|c|}
\hline \multirow{2}{*}{\multicolumn{2}{|c|}{ Weed Type, Species, and Life Cycle * }} & \multicolumn{2}{|c|}{ CT } & \multicolumn{2}{|c|}{ SP } & \multicolumn{2}{|c|}{ BP } & \multicolumn{2}{|c|}{ NT } \\
\hline & & \multirow{2}{*}{$\frac{\mathbf{M}_{20}}{-}$} & \multirow{2}{*}{$\frac{\mathbf{M}_{50}}{-}$} & \multirow{2}{*}{$\frac{\mathbf{M}_{\mathbf{2 0}}}{413^{\mathrm{i}}}$} & \multirow{2}{*}{$\frac{\mathbf{M}_{50}}{372^{\mathrm{i}}}$} & \multirow{2}{*}{$\begin{array}{c}\mathbf{M}_{20} \\
-\end{array}$} & \multirow{2}{*}{$\begin{array}{c}\mathbf{M}_{50} \\
-\end{array}$} & \multirow{2}{*}{$\frac{\mathbf{M}_{\mathbf{2 0}}}{570^{\mathrm{i}}}$} & \multirow{2}{*}{$\frac{\mathbf{M}_{50}}{687^{\mathrm{i}}}$} \\
\hline 1. Alternanthera denticulata R. Brown. & Perennial & & & & & & & & \\
\hline 2. Amaranthus spinosus L. & Annual & 245 & 224 & - & - & 156 & - & 199 & - \\
\hline 3. Commelina benghalensis L. & Annual & - & 210 & - & - & 171 & $284^{\mathrm{iii}}$ & - & - \\
\hline 4. Cyanotis axillaris Roem. & Annual & - & - & - & - & 322 iii & 112 & 328 & - \\
\hline 5. Dentella repens L. & Perennial & - & - & $361^{\mathrm{iii}}$ & $343^{\mathrm{ii}}$ & $479^{\mathrm{i}}$ & 247 & $473^{\mathrm{ii}}$ & $502^{\text {iv }}$ \\
\hline 6. Eclipta alba L. & Annual & 210 & 231 & - & - & 230 & - & 126 & 179 \\
\hline 7. Euphorbia parviflora L. & Annual & 219 & $346^{\mathrm{i}}$ & - & - & 140 & 195 & - & 125 \\
\hline 8. Hedyotis corymbosa (L.) Lamk. & Annual & - & - & 151 & $287^{\mathrm{iii}}$ & 128 & 251 & 322 & 302 \\
\hline 9. Jussia deccurence Walt. & Perennial & 299 iii & $272^{v}$ & $349^{\text {iv }}$ & 280 iv & $469^{\mathrm{ii}}$ & - & $449^{\text {iv }}$ & $611^{\text {ii }}$ \\
\hline 10. Lindernia antipoda Alston. & Annual & 323 & 280 iv & 219 & 171 & 84 & $269^{v}$ & 349 & 364 \\
\hline 11. L. hyssopifolia L. & Annual & 271 iv & 267 & 287 & 223 & 207 & 128 & 336 & 278 \\
\hline 12. Monochoria hastata L. & Annual & 309 ii & 289 iii & - & - & 210 & 201 & - & - \\
\hline 13. Rotala ramosior (L.) Koehne. & Annual & - & - & - & - & - & - & 301 & - \\
\hline 14. Solanum torvum $\mathrm{Sw}$. & Perennial & - & - & $318^{\mathrm{v}}$ & 217 & - & - & $409^{\mathrm{v}}$ & $437^{\mathrm{v}}$ \\
\hline 15. Spilanthes acmella Murr. & Annual & 270 & - & - & - & 139 & - & 85 & - \\
\hline 16. Digitaria sanguinalis L. & Annual & 212 & $343^{\mathrm{ii}}$ & - & - & 147 & 297 ii & 190 & 380 \\
\hline 17. Echinochloa colonum L. & Annual & 270 & 248 & 212 & $264^{\mathrm{v}}$ & 159 & $270^{\text {iv }}$ & 348 & 359 \\
\hline 18. E. crusgalli L. & Annual & - & - & - & - & - & - & 340 & - \\
\hline 19. Eleusine indica L. & Annual & 213 & - & - & - & $265^{v}$ & 189 & 474 & 327 \\
\hline 20. Leersia hexandra L. & Perennial & - & - & $372^{\mathrm{ii}}$ & - & - & - & - & - \\
\hline 21. Cyperus difformis L. & Annual & 283 & - & - & - & 158 & 117 & 370 & 359 \\
\hline 22. C. iria L. & Annual & $340^{\mathrm{i}}$ & - & - & - & 234 & 131 & 268 & 347 \\
\hline 23. C. rotundus L. & Perennial & - & - & 284 & 208 & 309 iv & $589^{i}$ & $494^{\mathrm{ii}}$ & $521^{\mathrm{iii}}$ \\
\hline 24. Fimbristylis miliacea L. & Annual & $264^{\mathrm{v}}$ & 246 & - & - & 146 & 147 & 245 & 286 \\
\hline Number of weed species & & $14^{\mathrm{bcd}}$ & $11^{\mathrm{cd}}$ & $10^{\mathrm{cd}}$ & $9^{e}$ & $17^{\mathrm{ab}}$ & $15 b^{c}$ & $19^{a}$ & $16^{\mathrm{ab}}$ \\
\hline Weed density (plants $\mathrm{m}^{-2}$ ) & & $3708^{\mathrm{cd}}$ & $2956^{\mathrm{e}}$ & $2966^{\mathrm{e}}$ & $2365^{f}$ & $4153^{c}$ & $3427^{d}$ & $6881^{a}$ & $6064^{b}$ \\
\hline Diversity index $\left(\mathrm{H}^{\prime}\right)$ & & 2.61 & 2.39 & 2.35 & 2.28 & 2.78 & 2.76 & 2.95 & 2.93 \\
\hline Dominance index (SI) & & 0.53 & 0.51 & 0.63 & 0.63 & 0.55 & 0.51 & 0.53 & 0.49 \\
\hline
\end{tabular}

${ }^{*} 1-15$ = broadleaf, $16-20$ = grass, $21-24=$ sedge, $\mathrm{CT}=$ conventional tillage, $\mathrm{SP}=$ strip planting, $\mathrm{BP}=$ bed planting, $\mathrm{NT}=$ no tillage, $\mathrm{M}_{20}=20 \%$ mulch, $\mathrm{M}_{50}=50 \%$ mulch, $\mathrm{i}-\mathrm{v}=$ five most dominant species, $-=$ absent. Values are means of four replicates. The means with similar letters (a-f) do not differ significantly at $p \leq 0.05$. Co-efficient of variance $(\mathrm{CV})$ and standard errors $(\mathrm{SE} \pm$ ) for the number of weed species were $22.7 \%$ and 1.11 , respectively; and for weed density (plants $\mathrm{m}^{-2}$ ) values were $29.6 \%$ and 563 , respectively.

The diversity and dominance indices of CT were lower than those of BP, indicating the evenly distributed, less diversified weed seedbank in CT. Mostly, the annual species was found to dominate the CT. Euphorbia parviflora, Cyperus iria, Monochoria hastata, Jussia deccurence, Digitaria sanguinalis, Lindernia antipoda, L. hyssopifolia, and Fimbristylis miliacea were the dominant weed species (Table 1). A retention of 50\% residue with all the tillage types decreased the diversity and dominance of the weed species in the seedbank (Table 1).

In Digram, after the SP + 50\% residue, 18 species emerged, while BP with $20 \%$ and $50 \%$ residue produced 25 and 23 weed species, respectively. Overall, there were fewer weed species in SP, followed by BP and CT. A retention of $50 \%$ residue produced $21 \%$ fewer weed species numbers than 20\% residue mulch in SP. This reduction was $19 \%$ in CT and $8 \%$ in BP (Table 2). 
Table 2. Seedbank composition and weed density $\left(\right.$ plants $\mathrm{m}^{-2}$ ) as affected by tillage and residue mulch treatments in Digram after 5 years.

\begin{tabular}{|c|c|c|c|c|c|c|c|}
\hline \multirow{2}{*}{\multicolumn{2}{|c|}{ Weed Type, Species, and Life Cycle * }} & \multicolumn{2}{|c|}{ CT } & \multicolumn{2}{|c|}{ SP } & \multicolumn{2}{|c|}{ BP } \\
\hline & & \multirow{2}{*}{$\begin{array}{r}\mathbf{M}_{20} \\
154\end{array}$} & \multirow{2}{*}{$\frac{\mathbf{M}_{\mathbf{5 0}}}{139}$} & \multirow{2}{*}{$\begin{array}{c}\mathbf{M}_{\mathbf{2 0}} \\
211\end{array}$} & \multirow{2}{*}{$\begin{array}{c}\mathbf{M}_{\mathbf{5 0}} \\
176\end{array}$} & \multirow{2}{*}{$\begin{array}{r}\mathbf{M}_{\mathbf{2 0}} \\
237\end{array}$} & \multirow{2}{*}{$\begin{array}{r}\mathbf{M}_{\mathbf{5 0}} \\
115\end{array}$} \\
\hline 1. Amaranthus viridis L. & Annual & & & & & & \\
\hline 2. A. spinosus L. & Annual & 148 & 123 & 187 & 103 & 205 & 231 \\
\hline 3. Chenopodium album $\mathrm{L}$. & Annual & 149 & - & 122 & - & 199 & - \\
\hline 4. Commelina benghalensis L. & Annual & 172 & 144 & 163 & - & 187 & - \\
\hline 5. Cyanotis axillaris Roem. & Annual & 106 & 154 & - & 190 & - & 78 \\
\hline 6. Dentella repens L. & Annual & 161 & $172^{\mathrm{iv}}$ & 141 & - & $230^{v}$ & 129 \\
\hline 7. Eclipta alba L. & Annual & 159 & 119 & - & 173 & - & 321 \\
\hline 8. Euphorbia parviflora L. & Annual & 157 & 135 & - & - & - & 189 \\
\hline 9. E. hirta L. & Annual & 159 & - & 101 & 145 & 207 & 138 \\
\hline 10. Gomphrena sessilis L. & Perennial & 141 & 99 & 209 & 109 & 186 & $462^{i}$ \\
\hline 11. Hedyotis orymbose Lamk. & Annual & 123 & 134 & 144 & - & 325 iii & $247^{\mathrm{v}}$ \\
\hline 12. Jussia deccurence Walt. & Perennial & 138 & - & 258 & $213^{\mathrm{iv}}$ & $374^{\mathrm{i}}$ & $258^{\text {iv }}$ \\
\hline 13. Lindernia hyssopifolia L. & Annual & $168^{\mathrm{v}}$ & 147 & 156 & - & 198 & 176 \\
\hline 14. L. antipoda Alston. & Annual & $182^{\mathrm{ii}}$ & 101 & 141 & - & 259 iv & - \\
\hline 15. Monochoria hastata $\mathrm{L}$. & Annual & $176^{\mathrm{iv}}$ & 124 & 196 & 137 & 222 & 212 \\
\hline 16. M. vaginalis Burm. & Annual & $177^{\mathrm{iii}}$ & 136 & - & - & - & 99 \\
\hline 17. Physalis minima L. & Annual & 139 & 151 & - & - & - & - \\
\hline 18. Rotala ramosior (L.) Koehne. & Annual & 132 & - & 222 & 184 & 219 & 189 \\
\hline 19. Solanum torvum Sw. & Perennial & - & 131 & $269^{\text {iii }}$ & 107 & - & 299 iii \\
\hline 20. Sphenoclea zeylanica Gaertn. & Annual & 147 & 128 & - & - & 137 & - \\
\hline 21. Spilanthes acmella Murr. & Annual & 137 & 137 & - & - & 153 & 232 \\
\hline 22. Digitaria sanguinalis L. & Annual & 149 & 135 & - & 87 & - & 241 \\
\hline 23. Echinochloa colonum L. & Annual & 124 & - & $245^{\mathrm{v}}$ & 199 & 103 & 222 \\
\hline 24. E. crusgalli L. & Annual & 116 & - & 174 & $208^{v}$ & 78 & - \\
\hline 25. Eleusine indica L. & Annual & 158 & 144 & 229 & 101 & 111 & 301 ii \\
\hline 26. Leersia hexandra L. & Perennial & 137 & 117 & $283^{\mathrm{ii}}$ & - & 104 & - \\
\hline 27. Cyperus difformis L. & Annual & 149 & $163^{\mathrm{v}}$ & 111 & - & 143 & - \\
\hline 28. C. iria L. & Annual & 105 & $181^{\mathrm{iii}}$ & - & - & 114 & - \\
\hline 29. C. rotundus L. & Perennial & - & - & $256^{\mathrm{iv}}$ & $321^{\mathrm{i}}$ & 354 ii & 241 \\
\hline 30. Eleocharisatro purpurea Re. & Annual & 152 & $196^{\mathrm{i}}$ & 106 & 152 & 207 & 211 \\
\hline 31. Fimbristylis miliacea L. & Annual & $228^{i}$ & $185^{\mathrm{ii}}$ & $289^{i}$ & 263 iii & 219 & 146 \\
\hline 32. Scripus supinus L. & Perennial & 142 & 169 & 132 & $302^{\mathrm{ii}}$ & 233 & 158 \\
\hline Number of weed spe & & $29^{a}$ & $25^{b}$ & $23^{b c}$ & $18^{\mathrm{d}}$ & $25^{b}$ & $23^{b c}$ \\
\hline Weed density (plants & & $4485^{\mathrm{b}}$ & $3564^{c}$ & $4316^{\mathrm{b}}$ & $3170^{d}$ & $5004^{\mathrm{a}}$ & $4895^{\mathrm{a}}$ \\
\hline Diversity index $(\mathrm{H}$ & & 3.09 & 3.06 & 3.01 & 2.83 & 3.39 & 3.20 \\
\hline Dominance index & & 0.41 & 0.39 & 0.59 & 0.59 & 0.50 & 0.48 \\
\hline
\end{tabular}

$* 1-21=$ broadleaf, $22-26$ = grass, $27-32=$ sedge, $\mathrm{CT}=$ conventional tillage, $\mathrm{SP}=$ strip planting, $\mathrm{BP}=$ bed planting, $\mathrm{M}_{20}=20 \%$ mulch, $\mathrm{M}_{50}=50 \%$ mulch, $\mathrm{i}-\mathrm{v}=$ five most dominant species, $-=$ absent. Values are means of four replicates. The means with similar letters (a-d) do not differ significantly at $p \leq 0.05$. Where, co-efficient of variance (CV) and standard error (SE \pm ) for the number of weed species were $19.2 \%$ and 1.86 , respectively; and for weed density (plants $\mathrm{m}^{-2}$ ) values were $17.3 \%$ and 298 , respectively.

In the $\mathrm{CT}+20 \%$ residue, 29 weed species were found, while the $\mathrm{CT}+50 \%$ residue had 25 weed species (Table 2). On the other hand, the SP $+20 \%$ residue produced 23 weed species. Based on the importance value of the five most dominant species, the annuals were dominant over the perennials.

Overall, the highest number of weed species and weed plant density in the seedbank were found under the $\mathrm{BP}+20 \%$ residue, but the richest composition of species was found in the $\mathrm{CT}+20 \%$ residue. The SP $+50 \%$ residue has the lowest species richness and the lowest species density $\mathrm{m}^{-2}$. A retention of $50 \%$ residue was beneficial in reducing both the species richness and density under all the tillage systems (Table 2). The lowest and highest values of diversity index (2.82) and dominance index (0.63) in the seedbank with $50 \%$ residue and SP indicated the least diversified population, but there was a dominance of some of the following weed species: Cyperus rotundus, Scripus supinus, Fimbristylis miliacea, Jussia deccurence, and Echinochloa crusgalli. The SP $+20 \%$ residue had comparable values of diversity in- 
dex (3.01) and dominance index (0.47), respectively. Admixtures of Fimbristylis miliacea, Leersia hexandra, Solanum torvum, Cyperus rotundus, and Echinochloa colonum dominated the seedbank in this practice. In terms of the five most dominant species, the perennial species were dominant over the annual species (Table 2).

The highest diversity index (3.39) in the BP $+20 \%$ residue $\left(5,004\right.$ plants $\mathrm{m}^{-2}$ comprising 25 species), plus the dominance index of 0.50 , indicated the most diversified composition of weed seedbank, followed by the BP $+50 \%$ residue ( 23 species produced 4,895 plants $\mathrm{m}^{-2}$ ). The mixture of perennial and annual species made the seedbank the most diverse, but it was dominated by perennial weeds: Jussia deccurence, Cyperus rotundus, Hedyotis corymbosa, L. antipoda, Dentella repens, Eleusine indica, and Solanum torvum (Table 2).

In the $\mathrm{CT}+20 \%$ residue, 29 species comprising 4,485 plants $\mathrm{m}^{-2}$ were measured, with diversity and dominance indices of 3.09 and 0.41 , respectively. As a result, this seedbank is more diverse than the $\mathrm{CT}+50 \%$ residue ( 25 species produced 3,564 plants $\mathrm{m}^{-2}$ ) and the SP treatments (Table 2). Mostly, the following annual weeds enriched the CT seedbank: Fimbristylis miliacea, Eleocharisatro purpurea, Lindernia antipoda, Cyperus iria, Monochoria hastata, M. vaginalis, Lindernia hyssopifolia, Dentella repens, and Cyperus difformis. Relatively lower values of both the indices were found in $50 \%$ residue retention than $20 \%$ (Table 2).

\subsection{Effect of Tillage and Residue Levels on the Similarity Co-efficient of SØrensen}

In Beluapara, the SP produced only 33\% similarity of weed species with CT, but 52 and $69 \%$ similarity of weeds with BP and NT, respectively. Moreover, BP had 96 and $88 \%$ similar weeds to CT and NT, respectively. On the other hand, NT produced $79 \%$ similarity to CT, of weeds in the seedbank, and $88 \%$ similarity with BP (Table 3). We found $86 \%$ similarity in weeds in the seedbank in $20 \%$ and $50 \%$ residue retention (Table 4 ).

Table 3. Effect of tillage practices on the SØrensen's qualitative and quantitative similarity index (\%) of the weed seedbank after 3 years in Beluapara and 5 years in Digram.

\begin{tabular}{|c|c|c|c|c|c|c|}
\hline & \multicolumn{6}{|c|}{ SØrensen's Qualitative Similarity Index (\%) } \\
\hline \multirow{8}{*}{$\begin{array}{l}\text { SØrensen's Quantitative } \\
\text { Similarity Index (\%) }\end{array}$} & Tillage & & CT & SP & BP & NT \\
\hline & \multirow{4}{*}{ Beluapara } & $\mathrm{CT}^{*}$ & - & 33 & 96 & 79 \\
\hline & & SP & 28 & - & 52 & 69 \\
\hline & & $\mathrm{BP}$ & 84 & 44 & - & 88 \\
\hline & & NT & 67 & 61 & 75 & - \\
\hline & \multirow{3}{*}{ Digram } & $\mathrm{CT}$ & - & 53 & 89 & - \\
\hline & & SP & 49 & - & 82 & - \\
\hline & & $\mathrm{BP}$ & 87 & 76 & - & - \\
\hline
\end{tabular}

*CT = conventional tillage, $\mathrm{SP}=$ strip planting, $\mathrm{BP}=$ bed planting, $\mathrm{NT}=$ no tillage.

Table 4. Effect of residue levels on the SØrensen's qualitative and quantitative similarity index (\%) of the weed seedbank after 3 years in Beluapara and 5 years in Digram.

\begin{tabular}{|c|c|c|c|c|}
\hline \multirow[b]{3}{*}{ SØrensen's Quantitative Similarity Index (\%) } & \multicolumn{4}{|c|}{ SØrensen's Qualitative Similarity Index (\%) } \\
\hline & \multicolumn{2}{|c|}{ Residue Levels } & \multirow{2}{*}{$\begin{array}{c}\mathbf{M}_{20} \\
- \\
81\end{array}$} & \multirow{2}{*}{$\begin{array}{c}\mathbf{M}_{\mathbf{5 0}} \\
86 \\
-\end{array}$} \\
\hline & Beluapara & $\begin{array}{c}\mathrm{M}_{20}{ }^{*} \\
\mathrm{M}_{50}\end{array}$ & & \\
\hline & Digram & $\begin{array}{l}\mathrm{M}_{20} \\
\mathrm{M}_{50}\end{array}$ & $\begin{array}{l}- \\
64\end{array}$ & $\begin{array}{c}77 \\
-\end{array}$ \\
\hline
\end{tabular}

${ }^{*} \mathrm{M}_{20}=20 \%$ mulch, $\mathrm{M}_{50}=50 \%$ mulch.

The composition of the weed seedbank in SP in Digram comprised a $53 \%$ and $82 \%$ similarity to that of CT and BP, respectively, while BP had $89 \%$ similar weeds to CT (Table 3). 
A retention of $50 \%$ crop residues produced $77 \%$ weed similarity in the seedbank to $20 \%$ residue (Table 4).

The quantitative similarity index had a lower value at both the sites than the qualitative index (Tables 3 and 4), meaning that there was more similarity in the species composition than in the number of common species. Based on the results, the SP and CT seedbanks were the least similar in terms of weed species composition. Moreover, the weed composition in CT and BP was the most similar, followed in order by CT and NT, SP and NT, and SP and BP.

\subsection{Effect of Different Tillage and Residue Retention on the Plant Abundance of Different Weed Types}

In Digram, the BP $+20 \%$ residue generated the highest total weed density, followed by CT and SP, both with $20 \%$ residue. On average, the SP $+50 \%$ residue had 237 fewer weeds $\mathrm{m}^{-2}$ than the $\mathrm{CT}+20 \%$ residue, but the $\mathrm{BP}+20 \%$ residue had 776 more weeds $\mathrm{m}^{-2}$ than the $\mathrm{CT}+20 \%$ residue (Table 5 ). The highest weed density resulted in the highest weed biomass in the $\mathrm{BP}+20 \%$ residue, followed by the $\mathrm{CT}+20 \%$ and $50 \%$ residue, while the lowest biomass of weeds was in the SP $+50 \%$ residue (Figure 1). The retention of 50\% residue produced 610 fewer weeds $\mathrm{m}^{-2}$ than $20 \%$ residue that led to a $39 \%$ reduction in weed biomass with $50 \%$ residue (Figure 1). Broadleaf weeds were the most dominant in all types of tillage, while grass weeds outnumbered the sedges in BP, but the reverse was found in SP. Annuals led over perennials in the CT $+20 \%$ residue, but perennials led over annuals both in SP and BP with 50\% residue (Figure 2).

Table 5. Effect of different tillage and residue mulch on the abundance (no. $\mathrm{m}^{-2}$ ) of different weeds in Digram after 5 years and in Beluapara after 3 years.

\begin{tabular}{|c|c|c|c|c|c|c|c|}
\hline \multirow{2}{*}{ Locations } & \multirow{2}{*}{ Treatments } & \multicolumn{2}{|c|}{ Broadleaf } & \multicolumn{2}{|c|}{ Grass } & \multicolumn{2}{|c|}{ Sedges } \\
\hline & & $\mathbf{M}_{20} *$ & $\mathbf{M}_{50}$ & $\mathbf{M}_{20}$ & $\mathbf{M}_{50}$ & $\mathbf{M}_{20}$ & $\mathbf{M}_{50}$ \\
\hline \multirow{3}{*}{ Digram } & Conventional tillage (CT) & $2691^{b}$ & $2257^{b}$ & $1065^{a}$ & $645^{b}$ & 729 bc & $662^{a}$ \\
\hline & Strip planting (SP) & $2460^{b c}$ & $2028^{b c}$ & $734^{\mathrm{b}}$ & $668^{b}$ & $1122^{\mathrm{a}}$ & $474^{\mathrm{c}}$ \\
\hline & Bed planting (BP) & $3136^{\mathrm{a}}$ & $3230^{a}$ & $1067^{\mathrm{a}}$ & $1028^{a}$ & $801^{b}$ & $637^{\mathrm{b}}$ \\
\hline \multirow{2}{*}{\multicolumn{2}{|c|}{$\begin{array}{c}\text { Co-efficient of Variance }(\mathrm{CV}(\%)) \\
\text { Standard Error }(\mathrm{SE} \pm)\end{array}$}} & 12.4 & 25.5 & 20.1 & 27.5 & 23.7 & 17.3 \\
\hline & & 198 & 368 & 111 & 124 & 121 & 59 \\
\hline \multirow{4}{*}{ Beluapara } & $\mathrm{CT}$ & $2403^{b}$ & $1567^{c}$ & $774^{c}$ & $591^{c}$ & $531^{c}$ & $798^{b}$ \\
\hline & SP & $1672^{d}$ & $1514^{\mathrm{c}}$ & $737^{c}$ & $496^{\mathrm{cd}}$ & $557^{c}$ & $355^{d}$ \\
\hline & $\mathrm{BP}$ & $2367^{b c}$ & $1919^{b}$ & $914^{\mathrm{b}}$ & $857^{\mathrm{b}}$ & $872^{b}$ & $651^{b c}$ \\
\hline & No tillage (NT) & $3440^{\mathrm{a}}$ & $3396^{a}$ & $2271^{a}$ & $1637^{\mathrm{a}}$ & $1170^{\mathrm{a}}$ & $1031^{\mathrm{a}}$ \\
\hline \multirow{2}{*}{\multicolumn{2}{|c|}{$\begin{array}{c}\text { CV }(\%) \\
\text { Standard Error }(S E \pm)\end{array}$}} & 28.9 & 22.1 & 25.6 & 27.8 & 23.5 & 24.9 \\
\hline & & 182 & 221 & 184 & 129 & 75 & 71 \\
\hline
\end{tabular}

${ }^{*} \mathrm{M}_{20}=20 \%$ residue, $\mathrm{M}_{50}=50 \%$ residue. Values are means of four replicates. The means for each weed group with similar letters (a-d) do not differ significantly at $p \leq 0.05$. 


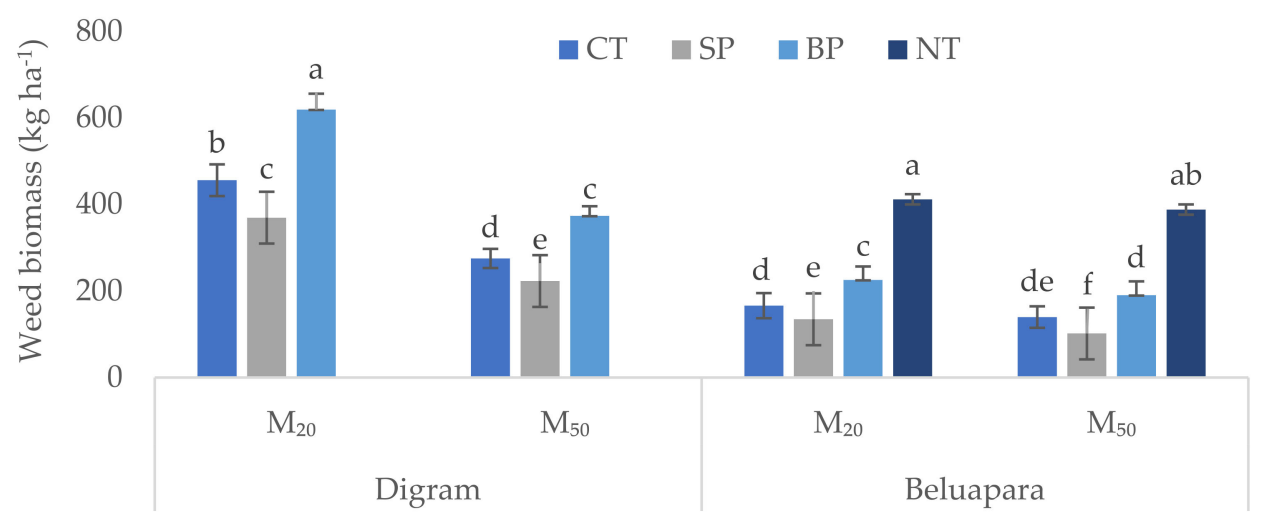

Figure 1. Effect of tillage practices and residue levels on the net weed dry biomass $\left(\mathrm{kg} \mathrm{ha}^{-1}\right)$ at 30 days after emergence from soil collected from Digram after 5 years and Beluapara after 3 years. Values are means of four replicates. The means for each site with similar letters $(\mathrm{a}-\mathrm{f})$ do not differ significantly at $p \leq 0.05$. $\mathrm{CT}=$ conventional tillage, $\mathrm{SP}=$ strip planting, $\mathrm{BP}=$ bed planting, $\mathrm{NT}=$ no tillage, $\mathrm{M}_{20}=20 \%$ residue, $\mathrm{M}_{50}=50 \%$ residue. Whiskers mean the standard deviation.

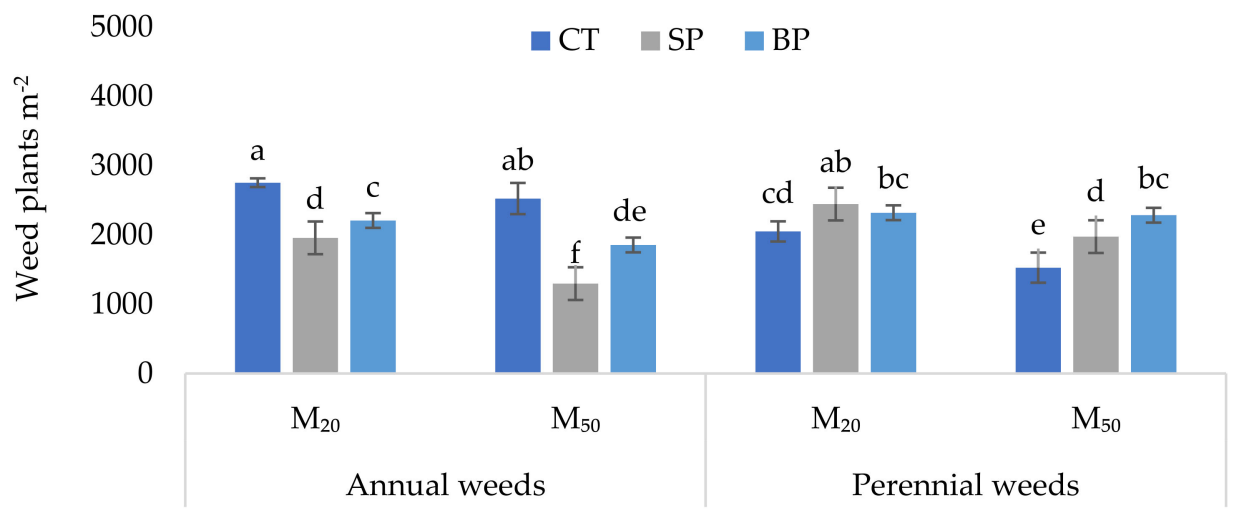

Figure 2. Density of emerged annual and perennial weeds from topsoil $(0-15 \mathrm{~cm})$ at 30 days after emergence from soil collected from Digram after 5 years under strip planting (SP), bed planting (BP) and conventional tillage (CT). Values are means of four replicates. The means with similar letters $(a-f)$ do not differ significantly at $p \leq 0.05 . \mathrm{M}_{20}=20 \%$ residue, $\mathrm{M}_{50}=50 \%$ residue. Whiskers mean the standard deviation.

In Beluapara, the lowest weed density was found in the $\mathrm{SP}+50 \%$ residue, while the retention of $20 \%$ residue with NT produced the highest weed density, followed by the same residue level with BP and CT. On average, relative to the CT $+20 \%$ residue $\left(1,668\right.$ weeds $\left.\mathrm{m}^{-2}\right)$, SP has 560 fewer weeds $\mathrm{m}^{-2}$, but BP and NT with $50 \%$ residue produced 386 and 2,639 more weeds $\mathrm{m}^{-2}$, respectively (Figure 3). Furthermore, we recorded the highest weed biomass at the NT $+20 \%$ residue, followed by BP and CT. The SP $+50 \%$ residue produced the lowest biomass, which was $19 \%$ less biomass than the CT $+20 \%$ residue (Figure 1). In all types of tillage and residue levels, broadleaf led over sedges and grasses. Annuals were dominant over perennials in $\mathrm{CT}$, but perennials led over annuals in SP, BP, and NT (Figure 3). 


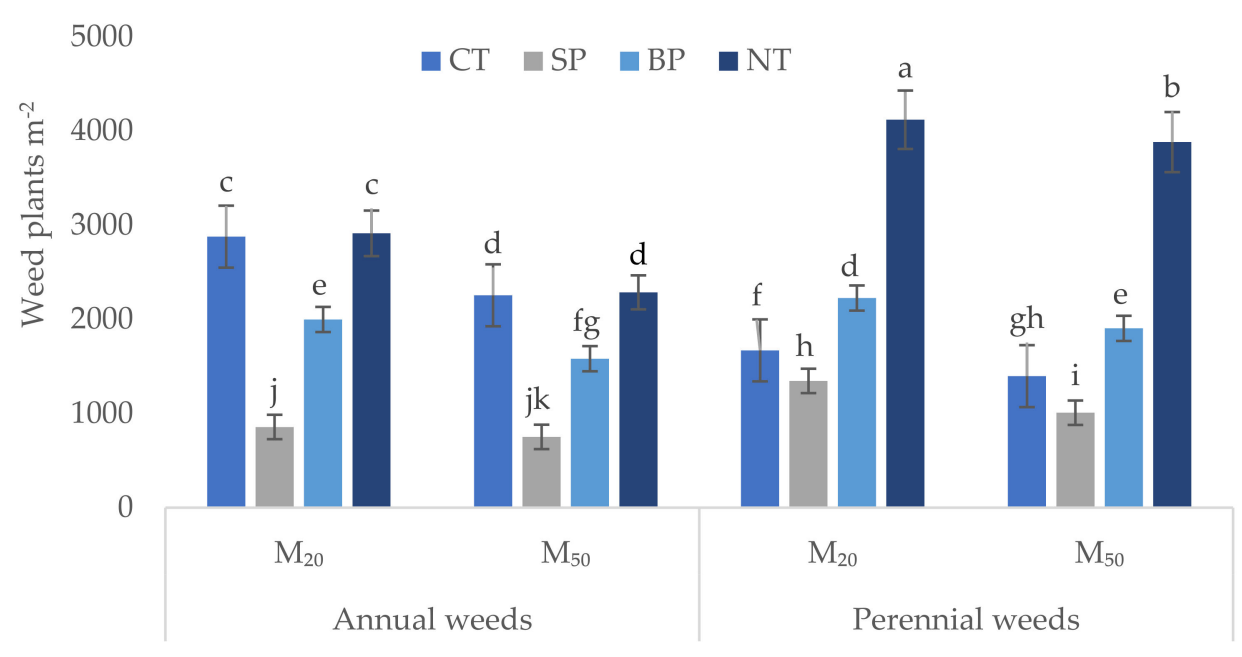

Figure 3. Density of emerged annual and perennial weeds from topsoil $(0-15 \mathrm{~cm})$ at 30 days after emergence collected from Beluapara after 3 years under strip planting (SP), bed planting (BP), no tillage (NT) and conventional tillage (CT). Values are means of four replicates. The means with similar letters $(\mathrm{a}-\mathrm{k})$ do not differ significantly at $p \leq 0.05 . \mathrm{M}_{20}=20 \%$ residue, $\mathrm{M}_{50}=50 \%$ residue. Whiskers mean the standard deviation.

\section{Discussion}

After 3-5 years of CA experiments, the seedbank of the SP $+50 \%$ crop residue was characterized by a significantly lower density of broadleaf, grass, and sedge types, and gross weed biomass, than the $\mathrm{CT}+20 \%$ residue at both the locations. In Digram, the $\mathrm{SP}+50 \%$ residue produced 2,028 broadleaf, 668 grass, and 474 sedge weed plant $\mathrm{m}^{-2}$, which was 25,37 , and $34 \%$ lower, respectively, than that of the CT $+20 \%$ residue. The reduction was $32-38 \%$ in Beluapara. The gross weed biomass of the SP $+50 \%$ residue was 51 and $39 \%$ lower than that of the CT $+20 \%$ residue; this was equivalent to 456 and $167 \mathrm{~kg} \mathrm{ha}^{-1}$ in Digram and Beluapara, respectively. The CT $+20 \%$ residue represents the current farm practice in the intensive rice-based crop rotations in the Eastern Gangetic Plain (EGP), while the $\mathrm{SP}+50 \%$ residue represents CA practice being recommended for smallholders [14]. Hence, these results suggest that the wider adoption of CA in the EGP will lessen the overall weed burden from crop management.

The suppression of the weed seedbank density and diversity after continuous SP $+50 \%$ residue for 3-5 years is attributed to minimal soil disturbance, plus the additive effect of reside retention for each of the three crops sown per year and the change in herbicide usage. Previous research suggests that a disturbance of about $80 \%$ of soil by CT [15] brings up dormant weed seeds from the deeper soil layers to the surface layer, which favors the higher germination of weed seeds and the emergence of weeds. The tilled soils of CT also offer a better germination medium for weed seeds, by increasing the aeration and temperature [1]. In the field, CT also allows seedlings to emerge from seeds that are buried deeper in the ground, compared to untilled soils in SP that may further increase the abundance of emerged weeds from the seedbank and alter the species composition in the weed seedbank of CT, relative to SP. However, in the present study, the soils were sampled to $15 \mathrm{~cm}$ depth in both CT and SP, and the soils were thoroughly mixed and spread to $3 \mathrm{~cm}$ depth. Hence, the present study may have overestimated the likely abundance of germinable weed seeds, by creating suitable germination conditions for seed that are normally buried too deep in CT, and especially in SP, to germinate and/or emerge. However, in another study, we found a lower weed density and biomass, and fewer weed species in the weed seedbank in soils sampled to only $0-5 \mathrm{~cm}$ under the SP $+50 \%$ residue retention, compared to CT after only 2 years [16]. Dormant seeds in CT become viable to germinate by scarification, ambient $\mathrm{CO}_{2}$ concentrations, and higher nitrate concentrations, which may lead to the production of a higher weed emergence of new weed species in plowed soils [17]. By 
contrast, owing to the stronger germination stimulus near the soil surface of less disturbed or no-till soil, a higher proportion of weed seeds will germinate in untilled soil than after plowing [18]. This might have led to a larger composition of seedbank in the NT than CT, followed by BP and SP, in this study.

The reduction in the number of weed species in SP might also be due to a cumulative effect of minimizing the weed seedbank status in the soil, by increasing non-viable or dormant weed seeds in the seedbank. Due to minimal soil disturbance (only $20 \%$ of the soil surface) in the upper soil layer in SP, most of the weed seeds remain on or close to the soil surface. They can lose viability, due to desiccation and an adverse climate [1]. The loss of seed viability in SP may also be attributed to increased seed dormancy in the undisturbed deeper soil layer, due to less oxygen pressure and darkness, which prevents the required germination triggers for these deeply buried seeds [19].

The surface accumulation of weed seeds in SP would increase predator (ants, insects, rodents, and birds) access to weed seeds, and could increase their removal rates. For example, common ground beetles or crickets can reduce weed seed emergence by 5 to $15 \%$ [20]. Overall, the adoption of SP may encourage seed losses via predation, by increasing the availability of seeds to predators, and by minimizing mortality and forced relocation of predators during tillage; therefore, reducing the weed seedbank size in SP. A higher dispersal of weed seeds may also lead to an increase in the seedbank in CT over SP, followed by BP and NT. Weed seeds traveled 2-3 $\mathrm{m}$ in the direction of full tillage, while in reduced tillage soils, the distance is negligible [21]. Reducing tillage in BP, and no tillage in SP and NT, therefore, reduced the physical spread of weed seeds both within and across fields. The reduced weed seedbank in SP, relative to NT, may also have occurred from additional weed seed burial, as strips cover about $20 \%$ of the surface area, but over successive plantings and years, they bury some seeds over most of the field.

The cumulative effect of herbicides applied probably also contributed to the lesser amount of weed seed set in the SP $+50 \%$ residue, followed by BP and NT, with and without residue. In the long-term CA plots, glyphosate and pendimethalin herbicide were used in all crops. Besides, ethoxysulfuron-ethyl was applied in rice, isoproturon in mustard, carfentrazone-ethyl + isoproturon in wheat, while fenoxaprop-p-ethyl was applied in jute, lentil, mungbean, and chickpea. These herbicides were previously reported to reduce seed set, which might have led to the reduction in weed pressure in SP, relative to CT. It was reported that a range of herbicides could reduce seed production and germination by several fold, depending on the biotypes. Glyphosate was found to suppress seed production by almost $100 \%$ in Ambrosia artemisiifolia L. [22]; pendimethalin herbicide decreased the seed germination of Chenopodium album L. by $31 \%$ [23]; and ethoxysulfuronethyl killed 98-100\% of the seeds of Echinochloa glabrescens L. [24]. Moreover, carfentrazoneethyl + isoproturon damaged $100 \%$ of the seeds of Emex spinosa L. [25], and fenoxapropp-ethyl ruined $97 \%$ of the seeds of Phalaris minor L. [26]. In addition, herbicide-induced seed dormancy has been reported in Hordeum murinum L., Bromus diandrus Roth., and Lolium rigidum Gaud. $[15,27]$. Hence, in the present study, herbicides could reduce the seed production and viability of weeds, thereby reducing the seedbank size in SP and, to a lesser extent, in BP and NT, relative to CT. Hossain et al. [28] reported a 30\% lower weed density and $40 \%$ lower weed biomass in SP than CT, when a pre- and post-emergence herbicide was used to control weeds in SP.

A retention of $50 \%$ residue, both with $\mathrm{SP}$ and $\mathrm{CT}$, reduced both the density and biomass of the seedbank weeds at both the locations. In Digram, the 50\% residue reduced the gross density and biomass by $30 \%$ and $40 \%$ in SP, but $25 \%$ and $36 \%$ in CT, respectively. We found $27 \%$ less density and $24 \%$ less biomass in $50 \%$ residue than $20 \%$ residue in SP than in CT in Beluapara. Fewer aboveground weed taxa in 50\% residue than $20 \%$ residue might be due to the effective suppression of germinated weeds, caused by the physical barrier of extra residue, lower soil temperatures, and allelochemicals released from decaying plant tissues in the field, as suggested by [29]. Moreover, reduced light penetration and cooler average soil temperatures in $50 \%$ residue, relative to $20 \%$ residue, could reduce weed 
seed germination or delay germination, damage of weed seeds, due to predation, and decomposition by macro and microbial populations [30]; delay emergence of etiolated plants that, in turn, produced fewer seeds, as stated earlier [31]. Comparatively higher and lower values of qualitative and quantitative similarity indices, respectively, in 50\% residue than $20 \%$ signify a more diversified weed seedbank in the $50 \%$ residue than the $20 \%$ residue in this study.

Chauhan and Abugho [32] observed that the emergence of weeds declined with increasing residue, and resulted in less weed biomass than with the no-residue treatment under reduced tillage. Similarly, Ngwira et al. [33] found double the weed biomass in NT without surface residue than NT with surface residue, retained at $6 \mathrm{th} \mathrm{h}^{-1}$. There is evidence that NT + residue encourages seed predation, increasing predatory seed depletion by two- to three-fold [34,35], as compared to conventional methods. Allelopathic suppression of weed seed germination through surface residue may be more effective in NT because seeds are concentrated near the soil surface, where the retained residue can release allelopathic compounds. Although pre-emergence herbicides are reported to be intercepted by the residue, those weeds that over-grow the residue can be killed effectively with the application of post-emergence herbicides $[1,36]$.

In Beluapara, the least diversified seedbank of the $\mathrm{SP}+50 \%$ residue had the lowest Shannon index (2.28) and the highest Simpson index (0.63) values in weed composition, with a dominance of particular weed species. The seedbank of the CT $+20 \%$ residue, which represents current farmers' practice, was more diversified than the SP $+50 \%$ residue, with Shannon and Simpson indices of 2.61 and 0.52, respectively. Similarly, in Digram, the $\mathrm{SP}+50 \%$ residue seedbank was the least diversified, in terms of the lowest and highest values of Shannon and Simpson indices of 2.83 and 0.59 , respectively. The seedbank of the CT $+20 \%$ residue was more diversified (values 3.09 and 0.41 , respectively) than the SP $+50 \%$ residue. In a similar study, which lasted only 2 years, Hossain et al. [16] reported a more diversified seedbank of CT without residue (with diversity and dominance indices of 2.93 and 0.54 , respectively), relative to the SP $+50 \%$ residue (indices of 2.44 and 0.90 , respectively), even though that study sampled soils to $5 \mathrm{~cm}$ depth rather than $15 \mathrm{~cm}$. In another study, Cardina et al. [37] found a decrease in species diversity with the increasing number of tillage operations; their diversity indices were $0.6,0.5$, and 0.2 in NT, RT, and CT, respectively). Sekutowski and Smagacz [38] reported a higher and lower coefficient of Shannon and Simpson in CT (2.55 and 0.08, respectively) than RT (1.61 and 0.22 , respectively). In contrast, Plaza et al. [39] discovered a more diversified RT seedbank (1.29) than CT, while NT was the least diversified (1.14), as did Woźniak [5], who reported a more diversified seedbank in RT (0.86) than CT (0.77). In another study, Feledyn-Szewczyk et al. [39] found that the least diversified NT seedbank was characterized by the lowest value of Shannon's diversity index (2.04) and a higher value of Simpson's domination index (0.18) than the RT $(2.18,0.18$, respectively) and CT (2.41 and 0.11 , respectively).

In Beluapara, a retention of 50\% residue decreased the diversity index with NT (2.93), $\mathrm{BP}$ (2.76), SP (2.28), and CT (2.39), relative to $20 \%$ residue (values were $2.95,2.78,2.35$, and 2.61 , respectively). Here, the dominance indices of $50 \%$ residue with NT, BP, SP, and CT were $0.49,0.51,0.63$, and 0.51 , respectively, while the indices of $20 \%$ residues were $0.53,0.55,0.63$, and 0.53 , respectively. Similarly, in Digram, the diversity and dominance indices of $50 \%$ residue, along with BP, SP, and CT, were 3.20 and $0.48,2.83$ and 0.59 , and 3.06 and 0.39 , respectively, while with $20 \%$ residue, the indices were 3.39 and $0.50,3.01$ and 0.47 , and 3.09 and 0.41 , respectively. Similarly, Hossain et al. [16] discovered that $50 \%$ residue with CT and SP had a lower diversity index (2.89 and 2.44, respectively) than no-residue (2.93 and 2.49, respectively). However, they found a lower dominance index of $50 \%$ residue $(0.90)$ than no-residue $(0.91)$ in RT, but the reverse in CT $(0.57$ and 0.54 , respectively). In Beluapara, relative to $\mathrm{CT}$, the most similar species composition was found in BP (96\%), followed by NT (79\%), and the least similar in SP (33\%). Similarly, in Diagram, the similarities in BP and SP were 89 and 53\%, respectively. Our finding was supported by Feledyn-Szewczyk et al. [40], who found about a 78\% similar weed species composition in 
NT and RT, respectively. In another study, Zanin et al. [41] discovered 83 and 66\% similar species compositions in NT and RT, respectively, relative to CT. In our study, the seedbank of $50 \%$ and $20 \%$ residue had 86 and $77 \%$ similar species compositions at the Beluapara and Digram sites, respectively. Hossain et al. [16] found 75\% similar species compositions (qualitative values) in RT and CT, and $86 \%$ similar species compositions in $50 \%$ residue and no-residue.

In the present study, the following annual weeds led over perennials in CT: Euphorbia parviflora, Cyperus iria, Monochoria hastata, Digitaria sanguinalis, Lindernia antipoda, L. hyssopifolia and Fimbristylis miliacea; however, the following perennial weeds were more abundant than annuals in SP, BP, and NT: Alternanthera denticulata, Leersia hexandra, Dentella repens, Jussia deccurence, Solanum torvum, and Cyperus rotundus. Many studies support our study reporting that CT systems favor annuals, while reduced tillage systems favor perennial weeds [42]. Thomas et al. [43] also observed the proliferation of annual species in the traditional tillage. The ecological succession theory [4] also suggests the dominancy of perennials weeds in less-disturbed systems, because CT kills most of the underground vegetative reproduction structures (rhizomes, tubers, bulbs, runner, and stolon) of perennial weeds, while annual weeds, which reproduce mostly by seeds, tend to be more competitive. On the other hand, reduced tillage in ST and BP, and NT preserves viable rhizomes, tubers, bulbs, runners, and stolons, which favor perennial weeds in the soil weed seedbank.

Herbicide application was found to be more effective to control perennial weeds under reduced or no-tillage systems in CA [44]. In-crop, preharvest, and postharvest herbicide applications can be used in perennial weed control schemes in crops. Regardless of the implementation method, retreatment once or twice a year is expected for effective control of perennial weeds. Using a knockdown herbicide, such as glyphosate, as in Roundup Ready maize, soybean, canola, and sugar beet is a highly successful method for controlling perennial weeds. Glyphosate-applied preharvest provided effective control of existing Cirsium arvense (Canada thistle). Postharvest herbicide applications were successful in treating new perennial weed growth. However, carefully designed herbicide programs are needed to combat perennial weeds in CA, while minimizing negative environmental effects and weed resistance to herbicide. Moreover, the persistence of herbicides in soils has an impact on the crop sequencing in CA rotations, especially when the herbicide is selective to the crop to which it is applied, but not to following crops $[45,46]$. This raises the issue of weed control tactic compatibility, since crop rotation is also a weed control method in CA [1]. Crop rotation disrupts the life cycle of weeds and reduces crop-weed specificity [47], thus decreasing weed persistence and its associated challenges. However, the efficacy of pre-emergence herbicides on the soil surface is diminished, due to crop residue interception [48]. This necessitates the use of a post-emergence herbicide. Crop residue can also be a source of weed seeds. However, the IWM approach of preventive weed management could effectively regulate perennial and annual weeds in CA $[48,49]$.

\section{Conclusions}

The soil weed seed bank (number of weeds $\mathrm{m}^{-2}$ ) decreased in SP by $13 \%$, and increased in BP and NT by 19\% and 76\%, respectively, compared with CT. The number of weed species reduced in both SP and NT, by $24 \%$ and $11 \%$, respectively, but increased in BP by $2 \%$. The lowest similarity of weed communities was found in the seedbank between SP and CT, indicating significant divergence of the seedbanks after 3-5 years. The seedbank under CT was dominated by the following annual weeds: Cyperus iria (L.), Digitaria sanguinalis (L.), Euphorbia parviflora (L.), Fimbristylis miliacea (L.), Lindernia antipoda (L.), L. hyssopifolia (L.), and Monochoria hastata (L.). On the other hand, the seedbank of SP, BP, and NT was dominantly perennial weeds, especially the following: Alternanthera denticulata ((R.) Brown.), Cyperus rotundus (L.), Dentella repens (L.), Jussia deccurence (Walt.), Leersia hexandra (L.), and Solanum torvum (Sw.). A retention of $50 \%$ of cereal crop residues also reduced the weed seedbank species composition (16\%) 
and diversity (14\%). We concluded that the continued strip planting-based conservation agriculture with $50 \%$ crop residue retention for 3-5 years reduced the weed seedbank size and diversity of weed species in the seedbank in contrasting rice-based cropping patterns. However, strip planting, bed planting, and no-tillage increased the proportion of perennial weeds in the weed seedbank, relative to the dominance of annual weeds in conventional tillage, and this may necessitate a change, over time, in weed control strategies. To verify this finding, a more extensive on-farm field study on the soil weed seedbanks under longterm conservation agriculture is suggested. Also, it is necessary to conduct research on the control of perennial weeds in conservation agriculture systems. Further research is also essential, in order to fully understand the complex relationships of weed species, and how they are affected by different tillage and residue mulch retention levels.

Author Contributions: Conceptualization, M.M.H., M.B. and M.M.R.; methodology, M.M.H. and A.H.; software, M.M.H.; validation, R.W.B., A.H. and M.B.; formal analysis, M.M.H. and M.M.R.; investigation, M.M.H., M.B., M.M.R.; resources, M.M.H.; data curation, M.M.H., M.B. and A.H.; writing-original draft preparation, M.M.H., R.W.B.; writing—review and editing, R.W.B., A.H. and M.E.H.; visualization, M.M.H. and A.H.; supervision, M.B., M.M.R.; project administration, M.B., R.W.B. and M.E.H.; funding acquisition, R.W.B.; All authors have read and agreed to the published version of the manuscript.

Funding: This research was funded by the Australian Centre for International Agricultural Research (ACIAR) project (LWR/2010/080), led by Murdoch University, Australia, and the APC was funded by Murdoch University.

Institutional Review Board Statement: Not applicable.

Data Availability Statement: Data are not publicly available, though the data may be made available on request from the corresponding author.

Acknowledgments: The authors thankfully acknowledge the research facilities provided by the department of Agronomy, Bangladesh Agricultural University.

Conflicts of Interest: The authors declare no conflict of interest.

\section{References}

1. Nichols, V.; Verhulst, N.; Cox, R.; Govaerts, B. Weed Dynamics and Conservation Agriculture Principles: A Review. Field Crop. Res. 2015, 183, 56-68. [CrossRef]

2. Pittelkow, C.M.; Liang, X.; Linquist, B.A.; Van Groenigen, L.J.; Lee, J.; Lundy, M.E.; Van Gestel, N.; Six, J.; Venterea, R.T.; Van Kessel, C. Productivity Limits and Potentials of the Principles of Conservation Agriculture. Nature 2015, 517, 365-368. [CrossRef]

3. Singh, M.; Bhullar, M.S.; Chauhan, B.S. Influence of Tillage, Cover Cropping, and Herbicides on Weeds and Productivity of Dry Direct-Seeded Rice. Soil Tillage Res. 2015, 147, 39-49. [CrossRef]

4. Aweto, A. Ecological Succession Theory and Models. In Shifting Cultivation and Secondary Succession in the Tropics; Aweto, A., Ed.; CABI: Wallingford, Oxfordshire, UK, 2013; pp. 116-130. [CrossRef]

5. Woźniak, A. Effect of Tillage System on the Structure of Weed Infestation of Winter Wheat. Span. J. Agric. Res. 2018, 16. [CrossRef]

6. Moonen, A.C.; Barberi, P. Size and Composition of the Weed Seedbank after 7 Years of Different Cover-Crop-Maize Management Systems. Weed Res. 2004, 44, 163-177. [CrossRef]

7. Bàrberi, P.; Lo Cascio, B. Long-Term Tillage and Crop Rotation Effects on Weed Seedbank Size and Composition. Weed Res. 2001, 41, 325-340. [CrossRef]

8. Hossain, M.; Sarker, M.; Haque, M. Status of Conservation Agriculture Based Tillage Technology for Crop Production in Bangladesh. Bangladesh J. Agric. Res. 2015, 40, 235-248. [CrossRef]

9. Haque, E.; Islam, A.; Hossain, M.; Bell, R.; Sayre, K. An Innovative Versatile Multi-Crop Planter for Crop Establishment Using Two-Wheel Tractors. Agric. Mech. Asia Afr. Lat. Am. 2017, 48, 33-37.

10. Chancellor, R.J. The Identification of Weed Seedlings of Farm and Garden. Blackwell Science Inc.: Oxford, UK, 1981.

11. Magurran, A.E. Diversity Indices and Species Abundance Models. In Ecological Diversity and Its Measurement; Magurran, A.E., Ed.; Springer: Dordrecht, The Netherlands, 1988; pp. 7-45. [CrossRef]

12. Shannon, C.E. A Mathematical Theory of Communication. Bell Syst. Tech. J. 1948, 27, 379-423. [CrossRef]

13. Simpson, E.H. Measurement of Diversity. Nature 1949, 163, 688. [CrossRef] 
14. Bell, R.; Haque, M.; Jahiruddin, M.; Rahman, M.; Begum, M.; Miah, M.; Islam, M.; Hossen, M.; Salahin, N.; Zahan, T.; et al. Conservation Agriculture for Rice-Based Intensive Cropping by Smallholders in the Eastern Gangetic Plain. Agriculture 2018, 9, 5. [CrossRef]

15. Dahlin, A.S.; Rusinamhodzi, L. Yield and Labor Relations of Sustainable Intensification Options for Smallholder Farmers in Sub-Saharan Africa. A Meta-analysis. Agron. Sustain. Dev. 2019, 39, 1-18. [CrossRef]

16. Hossain, M.M.; Begum, M.; Hashem, A.; Rahman, M.M.; Ahmed, S.; Hassan, M.M.; Javed, T.; Shabbir, R.; Hadifa, A.; El Sabagh, A.; et al. Strip Tillage and Crop Residue Retention Decrease the Size but Increase the Diversity of the Weed Seedbank under Intensive Rice-based Crop Rotations in Bangladesh. Agronomy 2021, 11, 1164. [CrossRef]

17. Cardina, J.; Herms, C.P.; Doohan, D.J. Crop Rotation and Tillage System Effects on Weed Seedbanks. Weed Sci. 2002, 50, 448-460. [CrossRef]

18. Gallandt, E.R.; Fuerst, E.P.; Kennedy, A.C. Effect of Tillage, Fungicide Seed Treatment, and Soil Fumigation on Seedbank Dynamics of Wild Oat (Avena fatua). Weed Sci. 2004, 52, 597-604. [CrossRef]

19. Oziegbe, M.; Faluyi, J.O.; Oluwaranti, A. Effect of Seed Age and Soil Texture on Germination of Some Ludwigia Species (Onagraceae) in Nigeria. Acta Bot. Croat. 2010, 69, 249-257.

20. White, S.S.; Renner, K.A.; Menalled, F.D.; Landis, D.A. Feeding Preferences of Weed Seed Predators and Effect on Weed Emergence. Weed Sci. 2007, 55, 606-612. [CrossRef]

21. Barroso, J.; Navarrete, L.; Sánchez Del Arco, M.J.; Fernandez-Quintanilla, C.; Lutman, P.J.W.; Perry, N.H.; Hull, R.I. Dispersal of Avena Fatua and Avena Sterilis Patches by Natural Dissemination, Soil Tillage and Combine Harvesters. Weed Res. 2006, 46, 118-128. [CrossRef]

22. Gauvrit, C.; Chauvel, B. Sensitivity of Ambrosia artemisiifolia to Glufosinate and Glyphosate at Various Developmental Stages. Weed Res. 2010, 50, 503-510. [CrossRef]

23. Tanveer, A.; Nadeem, M.A.; Ali, A.; Tahir, M.; Zamir, M.S.I. Germination Behaviour of Seeds from Herbicide Treated Plants of Chenopodium Album, L. Ann. Braz. Acad. Sci. 2009, 81, 873-879. [CrossRef]

24. Opeña, J.L.; Chauhan, B.S.; Baltazar, A.M. Seed Germination Ecology of Echinochloa glabrescens and Its Implication for Management in Rice (Oryza sativa L.). PLoS ONE 2014, 9, e92261. [CrossRef]

25. Javaid, M.M.; Tanveer, A.; Ahmad, R.; Yaseen, M.; Khaliq, A. Optimizing Activity of Herbicides at Reduced Rate on Emex Spinosa Campd. with Adjuvants. Planta Daninha 2012, 30, 425-435. [CrossRef]

26. Singh, R.; Pramanick, B.; Singh, A.; Kumar, S.; Kumar, A.; Singh, G. Bio-Efficacy of Fenoxaprop-p-Ethyl for Grassy Weed Control in Onion and Its Residual Effect on Succeeding Maize Crop. Indian J. Weed Sci. 2017, 49, 63-66.

27. Owen, M.J.; Goggin, D.E.; Powles, S.B. Intensive Cropping Systems Select for Greater Seed Dormancy and Increased Herbicide Resistance Levels in Lolium rigidum (Annual Ryegrass). Pest Manag. Sci. 2015, 71, 966-971. [CrossRef] [PubMed]

28. Hossain, M.; Begum, M.; Hashem, A.; Rahman, M.; Bell, R. Weed Control in Strip Planted Wheat under Conservation Agriculture Practice Is More Effective than Conventional Tillage. Sci. J. Crop. Sci. 2020, 9, 438-450. [CrossRef]

29. Curran, W.S. Persistence of Herbicides in Soil. Crop. Soils 2016, 49, 16-21. [CrossRef]

30. Conklin, A.; Susan, E.; Liebman, M.; Lambert, D.; Gallandt, E.; Halteman, W. Effects of Red Clover (Trifolium pratense) Green Manure and Compost Soil Amendments on Wild Mustard (Brassica kaber) Growth and Incidence of Disease. Plant Soil 2002, 238, 245-256. [CrossRef]

31. Begum, M.; Juraimi, A.S.; Rastan, S.O.B.S.; Amartalingam, R.; Man, A. Bin. Seedbank and Seedling Emergence Characteristics of Weeds in Ricefield Soils of the Muda Granary Area in North-West Peninsular Malaysia. Biotropia 2006, 13, 11-21. [CrossRef]

32. Chauhan, B.S.; Abugho, S.B. Effect of Crop Residue on Seedling Emergence and Growth of Selected Weed Species in a SprinklerIrrigated Zero-Till Dry-Seeded Rice System. Weed Sci. 2013, 61, 403-409. [CrossRef]

33. Ngwira, A.R.; Aune, J.B.; Thierfelder, C. On-Farm Evaluation of the Effects of the Principles and Components of Conservation Agriculture on Maize Yield and Weed Biomass in Malawi. Exp. Agric. 2014, 50, 591-610. [CrossRef]

34. Brust, G.E.; House, G.J. Weed Seed Destruction by Arthropods and Rodents in Low-Input Soybean Agroecosystems. Am. J. Altern. Agric. 1988, 3, 19-25. [CrossRef]

35. Menalled, F.D.; Smith, R.G.; Dauer, J.T.; Fox, T.B. Impact of Agricultural Management on Carabid Communities and Weed Seed Predation. Agric. Ecosyst. Environ. 2007, 118, 49-54. [CrossRef]

36. Chhokar, R.; Sharma, R.; Jat, G.; Kumar, A.; Gathala, M. Effect of Tillage and Herbicides on Weeds and Productivity of Wheat under Rice-Wheat Growing System. Crop. Prot. 2007, 26, 1689-1696. [CrossRef]

37. Cardina, J.; Regnier, E.; Harrison, K. Long-Term Tillage Effects on Seedbanks in Three Ohio Soils. Weed Sci. 1991, 39 186-194. [CrossRef]

38. Sekutowski, T.; Smagacz, J. Similarity between Soil Seedbank and Current Weed Infestation in Winter Wheat Cultivation. J. Res. Appl. Agric. Eng. 2011, 56, 96-98. Available online: https://www.pimr.eu/wp-content/uploads/2019/05/2011_4_SS.pdf (accessed on 1 September 2021).

39. Plaza, E.H.; Kozak, M.; Navarrete, L.; Gonzalez-Andujar, J.L. Tillage system did not affect weed diversity in a 23-year experiment in Mediterranean dryland. Agric. Ecosyst. Environ. 2010, 140, 102-105. [CrossRef]

40. Feledyn-Szewczyk, B.; Smagacz, J.; Kwiatkowski, C.A.; Harasim, E.; Woźniak, A. Weed Flora and Soil Seedbank Composition as Affected by Tillage System in Three-Year Crop Rotation. Agriculture 2020, 10, 186. [CrossRef] 
41. Zanin, G.; Otto, S.; Riello, L.; Borin, M. Ecological Interpretation of Weed Flora Dynamics under Different Tillage Systems. Agric. Ecosyst. Environ. 1997, 66, 177-188. [CrossRef]

42. Tuesca, D.; Puricelli, E.; Papa, J.C. A Long-Term Study of Weed Flora Shifts in Different Tillage Systems. Weed Res. 2001, 41, 369-382. [CrossRef]

43. Thomas, A.G.; Derksen, D.A.; Blackshaw, R.E.; Acker, R.C.V.; Légère, A.; Watson, P.R.; Turnbull, G.C.A. Multistudy Approach to Understanding Weed Population Shifts in Medium- to Long-Term Tillage Systems. Weed Sci. 2004, 52, 874-880. [CrossRef]

44. Todd, B.; Derksen, D. Perennial Weed Control in Wheat in Western Canada. In Wheat Production in Canada-A Review; Slinkard, A.E., Fowler, D.B., Eds.; University of Saskatchewan: Saskatoon, SK, Canada, 1986; pp. 391-404.

45. Busi, R.; Powles, S.B. Inheritance of 2,4-D Resistance Traits in Multiple Herbicide- Resistant Raphanus Raphanistrum Populations. Plant Sci. 2017, 257, 1-8. [CrossRef] [PubMed]

46. Heap, I. Global Perspective of Herbicide-Resistant Weeds. Pest Manag. Sci. 2014, 70, 1306-1315. [CrossRef] [PubMed]

47. Rao, V.S. Principles of Weed Science, 2nd ed.; Science Publishers, Inc.: Enfield, NH, USA, 2000.

48. Bahadur, S.; Verma, S.; Prasad, S.; Madane, A.; Maurya, S.; Kanaujia, G.; Verma, V.K.; Kumar, S. Eco-Friendly Weed Management for Sustainable Crop Production-A Review. J. Crop. Weed 2015, 11, 181-189.

49. Ayodele, O.; Olubunmi, A. Weed Management Strategies for Conservation Agriculture and Environmental Sustainability in Nigeria. IOSR J. Agric. Vet. Sci. 2017, 10, 1-8. [CrossRef] 